\title{
A TEOLOGIA NEGATIVA ENTRE PSEUDO-DIONÍSIO AEROPAGITA E MESTRE ECKHART
}

\section{SAULO MATIAS DOURADO ${ }^{1}$}

RESUMO: A tradição do pensamento místico se remete às origens da Idade Média, quando os textos platônicos são lidos por mestres cristãos. Pseudo-Dionísio Areopagita, autor da Teologia Mística, é um dos continuadores do neoplatonismo pelo viés religioso e, nesta obra, trata do princípio de negação que compreende Deus apenas pelas negações do que Ele não é. Em Mestre Eckhart, a questão sobre a natureza divina se torna também uma compreensão sobre o ser que transcende para o não-ser. O mestre renano desenvolve a partir das bases da teologia negativa e propõe uma ontologia a partir do conceito de deidade (Gottheit), que trata o Uno retirado de toda e qualquer forma a ponto de identificar-se com o próprio Nada.

PALAVRAS-CHAVE: Teologia Negativa, Pseudo-Dionísio Areopagita, Eckhart, Mística Cristã Medieval, Nada.

\begin{abstract}
The tradition of mystical thought refers back to the origins of the Middle Ages, when the Platonic texts are read by Christian thinkers. Pseudo-Dionysius the Areopagite, author of Mystical Theology, is one of the continuators of neo-Platonism by religious way, and in this work deals with the principle of denial that understands God only by the denials of what He is not. In Meister Eckhart, the question of the divine nature also becomes an understanding of being that transcends non-being. The rhenish master develops from the foundations of negative theology and proposes an ontology from the concept of deity (Gottheit), which treats the One withdrawn from any and each form, even identifying itself with Nothingness.
\end{abstract}

KEYWORDS: Negative Theology, Pseudo-Dionysian the Areopagite, Meister Eckhart, Medieval Christian Mysticism, Nothingness.

Os chamados neoplatônicos, que seguiam uma leitura de Platão focada no diálogo Parmênides com a correlação do ser e do Uno, tematizam uma teologia (theología) capaz de indicar a relação entre a alma e o divino (CARVALHO, 1996, p. 33). O inteligível se perfaz no sensível sem misturar-se a ele; o conhecimento busca, então, atingir a ideia pura através da união da alma em essência com o transcendente que escapa de toda corporeidade e contingência. Os representantes máximos do neoplatonismo são Plotino (+270) e Proclo (+487), contudo é Pseudo-Dionísio Areopagita quem extrai do neoplatonismo o fundamento de uma

\footnotetext{
1 Mestre em Filosofia pela Universidade Federal da Bahia (UFBA). Professor substituto de Filosofia pela Universidade do Estado da Bahia (UNEB). E-mail: saulomdourado@gmail.com.
} 
mística, numa passagem do paganismo para o cristianismo, e nomeia sua tentativa de compreender a natureza divina como uma Teologia Mística.

O texto de Pseudo-Dionísio ${ }^{2}$, datado do século V ou VI, traduzido por São Dinis e então disseminado por João Escoto na "Renascença Carolíngia", século IX, é dividido em cinco partes. Nas duas primeiras indica a natureza de Deus enquanto treva (gnóphos), isto é, ausência, obscuridade. Na terceira parte, trata das possibilidades afirmativas para expressar esta natureza tão acima da linguagem, a fim de então, na quarta e na quinta, manifestar as possibilidades negativas em se conceituar o divino. Pseudo-Dionísio conclui seu texto com uma série de negações para dizer o ser de Deus, a indicar que mais se aproxima da verdade aquele que diz o que Deus não é do que aquele que diz o que é.

\begin{abstract}
[...] a causa de todas as coisas não é alma nem inteligência, nem tem a ver com a imaginação, com a opinião, com a palavra, ou com o pensamento; pois nem é palavra nem pensamento, nem tão pouco se deixa dizer ou se deixa pensar; também não é número, nem ordem, nem extensão nem pequenez, nem igualdade ou desigualdade, semelhança ou dissemelhança; não está parada nem em movimento nem em repouso, não tem poder nem é poder ou luz; não vive nem é vida; não é substância nem eternidade ou tempo; não é intelectualmente apreensível como não é conhecimento, verdade, realeza, ou sabedoria, nem é um nem unidade, não é divindade ou bondade; tão pouco é espírito - tal como o conhecemos - ou filiação ou paternidade; ou qualquer outra coisa que nós ou outros entes possamos abarcar com o conhecimento; não é nenhuma das coisas que não existem nem das que existem, nem os seres a conhecem tal como ela é, nem ela mesma conhece os seres assim como eles são (PSEUDODIONÍSIO AREOPAGITA, 1996, p. 25).
\end{abstract}

A conceituação divina pela negação, como a lemos, introduz a teologia negativa (ou teologia apofática), que aponta a natureza da causa primeira como abscôndita, para além de toda e qualquer nomeação e ser. Tudo o que se possa pensar seria apenas uma aproximação do que Deus mesmo é, e ainda muito aquém do que verdadeiramente sua natureza seja. Para um conceito assim, que não pode ser apreendido nem pelos sentidos, nem pela inteligência - o que já é um descaminho do platonismo -, o único caminho é a união, a fim de se compreender o divino pela ascese do vazio da alma em encontro ao puro vazio de Deus.

A negatividade ou a apofaticidade de Pseudo-Dionísio é uma via de negação dos predicados racionais e objetivos à natureza divina, sobrepondo-a a todos os modos de seres. A superação do ser em Deus compreende-se como a recusa da inteligência em determinar a divindade, que é Causa e Uno, pela linguagem e pelo conhecimento. Em outros termos, a

\footnotetext{
2 O curioso nome se deve a um mal-entendido que percorreu a Idade Média. O autor se proclamou Dionísio do Areópago, presente na passagem do apóstolo Paulo em Atenas, nos anos cinquenta da era cristã (Atos dos Apóstolos 17,34), e em seus textos fazia questão de assinar como destinatários outros personagens bíblicos. Na historiografia do século XIX, verificou-se que seria impossível o texto ter sido escrito no período mencionado, já que se utiliza de passagens de Plotino e Proclo. Da identidade real se sabe apenas que ele provavelmente viveu no século V ou VI, na Síria. Cf. CARVALHO, 1996; CUNHA, 2009.
} 
negação divina não é apenas uma questão linguística, de que os homens não possuem as palavras adequadas para expressar sua natureza; é uma questão de ser, pois a identidade mesma divina está posta no Mistério.

Trata-se da negação para Deus tanto do entendimento de "Ser" (ov̉oía) ou de "Essência", seja da interpretação de uma existência individualizada ou do universal de uma determinada natureza. Se há distinções de ser e essência para os entes na criaturidade, para a deidade isto não é preciso, pois, seja a conotação de "Essência" ou "Ser", para uma doutrina da Divindade seria precisa utilizá-las com um aumentativo, Super-Ser, Super-Essência, como aproximações da compreensão teológica (CARVALHO, 1996, p. 77). Tais distinções metafísicas não ganham tanto relevo se Deus, por princípio, as ultrapassa. Deus não é um Ser entre outros, pois em sua natureza última habita em um plano onde não há nada além de si mesmo.

No terceiro capítulo da Teologia Mística, ao explicitar seu método, Pseudo-Dionísio é enfático quanto à diferença entre ser a sua questão apenas um problema de linguagem: “Assim também, agora, ao penetrarmos na treva que está acima do inteligível, não é a escassez de palavras que encontramos, mas uma completa privação delas, bem como do entendimento." (PSEUDO-DIONÍSIO, 1996, p. 21). Uma conceituação desse Mistério é inviável para as possibilidades da linguagem e do conhecimento, podendo ser ultrapassada apenas pela via mística, quando todos os nomes são abandonados. A natureza divina seria arrebatada pela alma, e o que o intelecto promove é a supressão de todo o desejo de conceito, a fim de encontrar o vazio, o nada.

Se Pseudo-Dionísio conclui um silenciamento, é para de novo regressar à especulação, na compreensão de Vaz (2000, p. 30), que define o pensador como "místico especulativo". A linguagem continua a expressar o Mistério, nem que seja apenas para mostrar os seus contornos. Num diálogo que passa pelo paradoxo, próprio do modo de expressão místico, Deus seria a treva que brilha, o vazio que transborda, o nada que cria. "Por ser causa de todas as coisas, mas com mais razão se lhe devem negar todos elas, na medida em que [a causa] ultrapassa a realidade de todas as coisas" (PSEUDO-DIONÍSIO, 1996, p.13).

A expressão "teologia negativa" é também um dos seus reconhecidos paradoxos. $\mathrm{Na}$ Teologia Mística, a palavra negação aparece dialeticamente com a palavra afirmação: "Não por supor que as negações se opõem às afirmações, mas antes por que a causa é de longe anterior e superior às privações" (Idem). A própria concepção de teologia se define, assim, com novas antinomias: "O divino Bartolomeu afirma [...] que a teologia é imensa e mínima, e que o 
Evangelho é extenso e grande, ao mesmo tempo que conciso. Penso que ele o compreendeu de forma maravilhosa" (Idem). Portanto, há muito o que especular sobre o Mistério, porque de tudo o que se possa dizer ainda se disse pouco, e do mesmo modo, o que do Uno se pode apreender é o imediato, é o conciso, é o indivisível. Este Uno que só é alcançado pela transcendência do mundo sensível, herança platônica, torna-se também a ascese da alma para o Inefável que é Deus.

A ultrapassagem da herança platônica se firma no último capítulo da Teologia Mística, ao considerar que, se a Causa não é sensível, tampouco é inteligível. O conceito do que seja a deidade não se encontra entre as formas e os números, entre a alma e a inteligência; a definição também está acima de um Mundo das Ideias. Para Carvalho (1996, p. 79), a conclusão de Pseudo-Dionísio implica em lembrar que o neoplatonismo não é uma repetição platônica em novas roupagens, e sim um uso da base do filósofo dos diálogos para novos conceitos. No segmento neoplatônico de Pseudo-Dionísio Areopagita, ainda se acrescenta a alcunha de cristão. Compreende-se, assim, que o autor quer acrescentar a total "impensabilidade" e "indizibilidade" da causa transcendente. Dizer ou pensar o que seria a natureza do Mistério, indivisível, mas em eterno movimento, seria o mesmo que estancá-lo.

A influência de Pseudo-Dionísio Areopagita se estenderá pela tradição da mística cristã a tal ponto que, segundo Gilson, seu Corpus areopagiticum é "uma das fontes mais importantes do pensamento medieval" (GILSON, 2001, p. 83). Um dos cumes é a assimilação por parte de um doutor da Igreja, no século XIII, professor estrangeiro na Sorbonne logo após Tomás de Aquino e reitor na Turíngia, Johannes Eckhart, conhecido, depois de sua condenação por suspeita de heresia ${ }^{3}$, como Mestre Eckhart. A tentativa se fez por mostrar a radicalidade do método negativo de Pseudo-Dionísio no seio da escolástica, ao traduzir a natureza divina como um ser para além de todo-ser, nomeando-a como uma "deidade" ou um "Nada".

\section{A natureza divina em Mestre Eckhart}

Eckhart pergunta-se no Sermão 9 o que é Deus e qual é o lugar de Deus: "Vinte e quatro mestres reuniram-se e quiseram conversar sobre o que seria Deus. Encontraram-se num tempo marcado e cada qual disse a sua palavra" (ECKHART, 2006, p. 83) ${ }^{4}$. Desta reunião, Eckhart destaca três definições. A primeira diz: "Deus é algo frente a que todas as coisas mutáveis e

3 Sobre a condenação de Eckhart e sua biografia, podemos ler a tradução da bula papal inquisitória em GUERIZOLI, 2000.

4 Um dos símbolos da expressão figurada que Eckhart atribuía aos seus ouvintes comuns se encontra aí. Esta reunião não existiu, é um modo de citar as definições de Deus no Liber 24 philosophorum, de Pseudo-Hermes Trismegistus (GIACHINI, 2006, p. 83). 
temporais nada são e, diante dele, tudo o que possui ser é insignificante". Já na segunda se mostra: "Deus é algo que necessariamente é e está além do ser, não carecendo em si mesmo de ninguém, mas de que todas as coisas carecem". A terceira, e última, assim se expressa: "Deus é uma compreensão que aí vive unicamente no conhecimento de si mesmo".

A tríade poderia ser representada a partir dos seus advérbios de lugar: "frente", "além" e "aí" (SCHUBACK, 2000, p. 55). No envolvimento de cada um deles, desponta a relação essencial de Deus. Eckhart escolhe o segundo, o "além", ao prosseguir o sermão. Para compreender a escolha, porém, é interessante perscrutar a rejeição. O que há nos demais advérbios que não revelam propriamente a natureza divina e quais pistas já nos dão acerca desta?

Primeiro, o advérbio "frente". Os sinônimos seriam "diante de" e "perante". Podemos usá-los ao indicar que, espacialmente, um ente está separado de outro a certa distância, de tal maneira que se possa ver e distinguir um e outro. Não há como dizer de algo que esteja dentro de um recipiente, por exemplo, que ele esteja à frente. O caráter separatório e distintivo compõe o modo relacional de tal advérbio. Dessa forma, se, no entendimento teológico apresentado por Eckhart, falássemos de Deus enquanto frente às criaturas, falaríamos de um Deus que não está nas criaturas e sim em separado.

Na segunda visão, encontra-se o advérbio "aí". O seu conteúdo, ao contrário de um “perante”, não demarca, não específica. O que está "aí" amontoa-se, liga-se ou junta-se, porque faz parte de um ponto que é um mesmo. No uso da expressão "estão aí", não pontuamos a diferença entre o que se encontra em um espaço, unifica-se o que nele se põe. A conjuntura do "aí" é a de apresentar-se na identidade, sem que se saiba o que é um e o que é o outro. Ao reportarmos a Deus a forma deste advérbio, podemos retirar de Deus as diferenças no que tangem às criaturas, de tal modo que criador e criatura são idênticos, em um mesmo ser.

Nos dois casos, recusam-se extremos: uma total separação de Deus enquanto pura transcendência ou uma total identificação de Deus enquanto pura imanência (SCHUBACK, 2000, p. 55). Deus não estaria assim nem ausente de criaturas, nem idêntico a elas, numa espécie de panteísmo. O que Eckhart aponta é uma relação em que Deus se torna presente nas criaturas e se faz nas criaturas, isto é, nos seres, sem misturar-se a qualquer uma destas criaturas ou seres. A escolha pelo "além" se mostra como este meio, porque todo o "além" pressupõe algo que se mostra simultaneamente a algo que o ultrapassa. Deus é no ser $e$ além do ser, pois só assim ele seria Uno. 
A argumentação é simples, segundo o próprio parecer de Eckhart: "Deus é em todas as criaturas à medida que elas possuem ser, mas é e está além. Precisamente por ser em todas as criaturas, ele é e está além" (ECKHART, 2006, p. 88). Deus está presente em todas as criaturas, uma vez que ao ser ele o é absolutamente, e está além, porque está em todas. Deus é uno porque está em todas as coisas e está em todas as coisas porque é uno. O grau de necessidade é que, para ser desse modo, Deus seja sempre além de todas as coisas. De que outro modo haveria unidade, se Deus estivesse em uma coisa e não em outra, se fosse apenas de um ser e não de outro? Ele precisa ser de todas e só pode estar além. Nenhum ser assim o fixa, embora todo ser o contenha. Desse modo, Deus não pode movimentar-se apenas no ser, ele precisa ultrapassar o ser para doar-se em todos.

\begin{abstract}
Cada coisa opera no $<$ seu $>$ ser; nenhuma coisa pode operar para além do seu ser. O fogo não pode operar a não ser na madeira. Deus opera acima do ser, na imensidão, onde pode mover-se; ele opera no não-ser. Antes que houvesse ser, Deus operava, operava ser, quando ainda não havia ser. Mestres insensatos, de rude compreensão, dizem que Deus é um puro ser. Ele é tão elevado acima do ser como o anjo mais elevado é acima de uma mosca. Se eu chamasse Deus de um ser, diria algo tão incorreto como chamar o sol de pálido ou de preto. Deus não é nem isso nem aquilo (ECKHART, 2006, Sermão 9, p. 84).
\end{abstract}

Três novos argumentos se colocam aí para o próprio de Deus: 1) Se Deus se concentrasse em um ser, ele não poderia estar em todos. Se não está em qualquer ser em especial, ele “opera acima do ser, na imensidão, onde pode mover-se", mover-se pelo ser. Logo, o próprio de Deus não está em um ser. 2) Se Deus é a criação do ser, ele é anterioridade de todo ser. Se ele é anterior a todo ser, não pode ele mesmo ser um ser. Assim, o próprio de Deus não se completa em um ser (JARCZYK et LABARRIÈRE, 1995, p. 130). De cada ser, eu encontro Deus, pois nenhuma coisa opera a partir de si, e sim a partir de Deus, contudo, em nenhuma delas eu assento o lugar divino, que é lugar de todos os lugares. Sendo assim, Deus não é nem este nem aquele, nem isto, nem aquilo.

Fica retirado daí qualquer caráter fixo ao que seja a natureza divina. O ser que é dito acerca dele, conforme Eckhart cita Agostinho no De Trinitate, em que Deus é sábio sem sabedoria, bom sem bondade, e poderoso sem poder, é "o ser sem ser": "Deus não é nem ser nem bondade. A bondade prende-se ao ser e não alcança nada além do ser; pois se não houvesse nenhum ser, não haveria nenhuma bondade (...) Deus não é bom, nem melhor nem o melhor" (ECKHART, 2006, S. 9, p. 85). Todas as qualidades ainda são do ser, e Deus é ainda mais puro do que o ser. Quem quiser atribuir a Deus algo, mesmo que mais nobre, estará mentindo, pois todo algo depende do ser. 
Deus é antes "movimento": está, pois, mais ligado ao Verbo do que ao Substantivo. "Deus nomeou a si mesmo um "verbo", diz Eckhart, ao mencionar o primeiro versículo do Evangelho de João, cujo princípio de Deus é o Verbo. Nestes termos, Deus é mais o movimento da ação verbal do que o caráter fixo do substantivo. É o que faz Eckhart vê-lo mais na categoria da relação do que da substância, conforme prossegue no Sermão 9:

\footnotetext{
Pequenos mestres ensinam na escola que todos os seres são divididos em dez modos de ser, recusando a Deus todos os modos. Nenhum desses modos de ser toca a Deus, mas Deus também não carece de nenhum deles. O primeiro modo de ser, que possui o máximo de ser e no qual todas as coisas recebem seu ser, é a substância; e o último, que possui o mínimo de ser, chama-se relação, e em Deus, esse modo é igual ao maior de todos, igual ao que possui o máximo de ser (ECKHART, 2006, Sermão 9, pp. 84$85)$.
}

Os mestres a que Eckhart se refere são aqueles que ensinam a doutrina das categorias de Aristóteles, a partir da qual se considera que todo ser se diz de dez modos: entre eles substância e relação. Por que "pequenos"? Consideram que o grau máximo é a substância, aquela que faz uma coisa ser enquanto ser. Eckhart não acredita que o ente é enquanto o ente próprio e sim sempre a partir de outro. Deus também não seria no modo da substância, e sim da relação, pois é no doar de si mesmo que ele é o que é, tal como as coisas são na recepção deste doar. O grau máximo de ser em Deus é a relação. Ele é puro compartilhamento: “Deus (...) compartilha o que é seu porque é a partir de si mesmo que Ele é o que é, e em todos os dons que concede, ele se dá sempre primeiramente a si mesmo" (ECKHART, 2006, p. 85). Ele é a fonte da relação, contudo nunca é a partir de outro que Deus é: ele é indiviso em si mesmo, Deus é idêntico sempre a si mesmo.

Assim, o não-ser do Uno, onde Deus opera, é uma negação de ser que não significa negatividade ou nulidade, e sim pura positividade e ebulição. É por não se conter em ser nenhum que Deus é nada e não-ser, e é por estar em todas as coisas e não em coisa alguma que Deus é deidade (Gottheit). Na tradução de Jarczyk e Labarrière (1995, p. 27), a deidade seria "Deus além de Deus"; não no sentido da existência de um supra-Deus, e sim na compreensão do princípio divino para além de toda e qualquer imagem. O princípio divino, em sua natureza mais originária, é um não-ser que está para além de todo ser no nome Deus.

\section{O Nada}

No tratado dos Nomes Divinos, Pseudo-Dionísio Areopagita diz que Deus, por “não ser nada do que é, não pode ser conhecido pelo que é, e, por não ser nada em nada, é conhecido por tudo em tudo, ao mesmo tempo em que não pode ser conhecido através de nada" (AREOPAGITA, P.-D, 869 D, 1943, apud. e trad. por CUNHA, 2015, p. 48). Eckhart no sermão 
82 também define: "Deus é nada; mas não que ele seja sem ser: ele não é nem isso nem aquilo, que possamos expressar; ele é um ser acima de todo ser. Ele é um ser sem ser" (ECKHART, 2009 , p. 116). No sermão 83, ele sintetiza, de modo quase contraditório ao trecho anterior, pelo paradoxo mesmo da linguagem mística: "Se digo 'Deus é um Ser', não é verdade: ele é um ser e um nada superior ao ser" (ECKHART, 2009, p. 118).

No Sermão 71, Mestre Eckhart comenta a passagem bíblica em que Paulo cai do cavalo e, ao levantar-se da terra, "nada vê" (At 9,8). Quatro sentidos para a palavra "nada" são considerados:

Um sentido é quando se levantou da terra e de olhos abertos nada via, esse nada era Deus; pois quando viu a Deus ele o chamou de um nada. O segundo sentido: quando se levantou, ele ali nada viu senão Deus. $O$ terceiro: nada via em todas as coisas senão Deus. O quarto: quando viu a Deus, viu então todas as coisas como um nada (ECKHART, 2009, p. 64).

Tais possibilidades de compreensão para a mesma palavra podem parecer levantamento de hipóteses, das quais se extrairá uma como legítima. A aparente contradição entre elas confirmaria a nossa leitura, afinal ou Deus é um nada ou todas as coisas é que são um nada e Deus é o que se faz como visto. Contudo, na continuidade do texto, Eckhart comenta cada sentido como um "lugar" ou "motivo", sem excluir nenhum, ou colocá-lo em oposição contra outro: são sentidos que convivem com um mesmo princípio. Ao passo que se repete três vezes a expressão "Deus é um ser que contém em si todo ser" ao longo do texto, expõe-se de que modo ele é um puro nada. Eckhart mantém a dupla consideração, sem configurar uma dicotomia, na interpretação do primeiro sentido:

\footnotetext{
Paulo levantou-se da terra e de olhos abertos nada via”. Eu não posso ver o que é Um. Ele nada via, isto era Deus. Deus é um nada e Deus é um algo. O que é algo também é nada. O que Deus é, isso ele o é inteiramente. Por isso, Dionísio, o iluminado, sempre que escreve de Deus, diz: Ele é sobre-ser, ele é sobre-vida, ele é sobre-luz; ele não the atribui nem "isso" nem "aquilo", e com isso indica que Deus seria um não-quê, portanto não algo-quê que esteja bem longe, além, acima. Quando alguém vê algo ou quando algo cai em teu conhecimento, isso não é Deus; justamente porque ele não é nem isso nem aquilo. (ECKHART, 2009, p. 67).
}

Pseudo-Dionísio, a toda vez que nomeia o divino, utiliza o sufixo "sobre" ou "super", tal como Eckhart o indicou: sobre-ser, sobre-vida, sobre-luz (GILSON, 2001, p. 81). Em nota de rodapé à tradução do sermão, Giachini lembra que o termo utilizado no original é Über e que não significa um "super-aumento do ente dentro de um determinado sentido do ser". Isto é, o Über leben não é uma "super-vida", uma potencialização máxima da vida, e sim uma "passagem", "na acepção de total desprendimento, do radical outro" (GIACHINI, 2006, p. 67). É um tornar-se e realizar-se para além do que já se é. Deus sempre ultrapassa, pois é "não algoquê" que está bem "longe, além, acima". 
Eckhart, antes, diz que Deus é um nada e é um algo. De que modo também poderia ser algo se está acima e é um nada por ser neste além e acima? O que pode esclarecer é o sentido mesmo de deidade, em que mesmo Deus está acima de Deus. Em Eckhart, existe o "Deus" para as criaturas e o Deus "para si mesmo", que é o Deus quoad nos e o Deus quoad se (GIACHINI, 2006, p. 334). Nas próprias palavras de Eckhart: "Antes de as criaturas serem, Deus < ainda> não era 'Deus': antes, ele era o que ele era. Mas, quando as criaturas se tornaram e receberam seu ser criado, Deus não era assim 'Deus' em si mesmo, mas 'Deus' nas criaturas” (ECKHART, 2006, S. 52, p. 289). O Deus que pode ser conhecido e nomeado é o Deus para as criaturas, ele é conhecido e nomeado no modo de apreensão da criatura, não por si mesmo. Este Deus nele mesmo e para ele mesmo só pode ser conhecido no não-conhecimento e não-nomeação. É a deidade acima do Deus das criaturas. Quem quer ver Deus na pureza, isto é, na deidade, deve ser cego e vê-lo fora do "algo"5.

De tudo o que se conhece, conhece-se por impressões a partir de coisas exteriores. Ao tomar uma impressão e tornar a coisa exterior um "algo", traz-se à alma algo estranho, porque não é da alma, tampouco é da coisa. É um estranho que vive entre os dois, sem ser de nenhum. O que se retira da coisa é uma exterioridade, e a alma é uma interioridade que em seu fundo está em si mesma (JARCZYK e LABARRIÈRE, 1995, p. 165). Se da primeira só tenho a imagem, e a alma por si só não é uma imagem para ela própria, a relação se dá pela estranheza, e uma é grosseira ao modo da outra.

Tomar também Deus pela impressão seria uma estranheza, pois este não é pela exterioridade, nem pela interioridade, é Uno e, portanto, indiviso e absoluto, como convergem os neoplatônicos (CUNHA, 2015, p.42). Pode-se pensar assim que Deus não é conhecido porque a sua capacidade de apreender seja limitada, de tal forma que só o faz a partir de impressões e imagens, e o problema da questão divina seja uma gnosiologia da razão e não uma ontologia do Uno. O conhecimento natural do homem é mesmo pela exterioridade, enquanto ele mesmo não se cega para o não-ser. Contudo, não se pode afirmar que a inefabilidade de Deus seja por conta da limitação das capacidades humanas e que supor uma "super-capacidade" possibilitaria conhecer Deus em si mesmo. Deus não é deidade por conta dos limites cognitivos da criatura humana, Deus é acima de si mesmo na deidade. Assim Eckhart é enfático em relação ao que se traz de Pseudo-Dionísio: o Nada está desde o princípio em Deus.

\footnotetext{
5 Quando Eckhart menciona Deus em seus sermões, não necessariamente fala do Deus das criaturas. A divisão conceitual não é nominal: ao mencionar Deus, ele inclui a deidade. Apenas quando quer fazer a distinção, ele traz "Deus" entre aspas, para indicar que o uso naquele momento é para Deus quoad nos ou quaod se. Na maior parte da escrita, Deus é sinônimo de deidade.
} 
O primado ontológico da deidade em relação às criaturas fica mais evidente no terceiro sentido que Eckhart traz no sermão, sem que o problema da esfera do conhecimento, ou seja, epistemológico, seja descartado:

\begin{abstract}
Além disso, em terceiro lugar, porque ele nada viu: é que "nada", isso era Deus. Um mestre diz: Em Deus todas as criaturas são como um nada, pois possui em si o ser de todas as criaturas. Ele é um ser que possui em si todo ser. Um mestre afirma que nada há abaixo de Deus, por mais próximo que dele seja, em que não incida algo de estranho. (...) Quando Paulo nada viu, então viu a Deus. A luz que é Deus emana para fora e torna escura toda luz. A luz na qual Paulo ali viu, nessa luz ele viu a Deus, nada mais (...) Pelo fato de ter sido envolto com a luz, ele nada mais viu; pois tudo que era da alma estava preocupado e ocupado com a luz que é Deus, de modo que não conseguia perceber nada de outro (ECKHART, 2009, p. 68).
\end{abstract}

Schürmann (2001 p. 155) sinaliza que a doutrina do ser em Eckhart parece-nos levar a uma aporia, uma vez que de um lado o ser é tudo o que é representado por um nome, por isso Deus está acima da representação e do ser, e de outro o ser é a totalidade de tudo em si mesmo, na direção em que Deus é todo ser. Em ambos os casos, remonta-se à expressão aristotélica de que "o ser se diz de muitos modos", desde substância à natureza, passando por essência e representação. Tratam-se de diferentes dimensões para o ser, em que o ser se diz desde a raiz da essência e da natureza ou como eclosão, ebulição. No caso, o ser de Deus enquanto essencialidade é a deidade, e deidade é nada, e esta essência é que dá ser a todas as criaturas, é pura eclosão de ser. A essência enquanto fonte das criaturas é Deus, e ele mesmo não é ser.

O caráter "paradoxal" parece mesmo uma aporia, mas é um modo mesmo de compreensão da questão do ser na mística eckhartiana. É um traço próprio, não apenas um problema de interpretação ou uma dificuldade de análise: está na característica da meta de tentar-se entender a natureza de Deus, uma vez que nos nomes nunca alcançamos o próprio de Deus e ainda assim pela sinuosidade dos nomes tentamos alcançá-lo. Este caminho levará a um abandono de um modelo lógico, no sentido aristotélico (GANDILLAC, 1995, p. 138). A imagem usada por Eckhart revela a necessidade paradoxal de sua expressão ${ }^{6}$ : Deus é uma luz no meio da escuridão, uma luz que torna escura as criaturas. É uma imagem bíblica que PseudoDionísio o Areopagita resgatou ao dizer que devemos ultrapassar as dualidades a ponto de a Treva ser a luz, e o não-saber, saber. Em Eckhart, a Luz também se dá na Escuridão. A Luz é fonte do ser, a Escuridão é o puro nada: os dois são modos distintos da mesma dimensão (JARCZYK e LABARRIÈRE, 1995 p. 150).

\footnotetext{
6 GANDILLAC, 1995, p. 138: "O que a razão julga impossível - ser e não ser conjuntamente - é a própria necessidade".
} 
Segundo Gilson, na passagem de pensamento entre a Teologia Mística e Os Nomes Divinos, Pseudo-Dionísio segue da teologia negativa, em que só há negações de Deus, para uma teologia superlativa, em que se reconhece a impossibilidade de um nome correto para o divino, mas ainda assim experiencia-se na linguagem o seu chamamento pela hipérbole (GILSON, 2001, p. 85). Podemos afirmar que Eckhart segue esta direção quando reconhece em sua ontologia a indefinição do princípio e o chama de "deidade", no entanto permite a correspondência pela alcunha do ser e da imagem. Em outras palavras, não seria porque a deidade para além de Deus é a natureza divina quoad se que o intelecto deva silenciar-se para expressar Deus quoad nos. Na correspondência entre os dois, o pensador reconhece os limites do segundo para o alcance da experiência mística do primeiro.

Mesmo sabendo-se Inefável e Absoluto o princípio que é Uno, ainda resta a linguagem e o conhecimento enquanto "louvor" ou "celebração" (hymneo). Nesta sequência, a superação de toda e qualquer possibilidade propositiva passa pela instauração de um modo diverso do dizer, do expressar, que Pseudo-Dionísio encontra como a via da eminência. Não apenas uma superação das vias afirmativa e negativa, é também uma forma de o pensante e falante encarar a aporia do seu discurso frente ao Inefável, ao Impensável e ao Absoluto e encontrar um caminho de alma para a compreensão e união (CARVALHO, 1996, p. 93.). Nas palavras do autor, é "celebrar o que é mais que substancial de um modo mais que substancial".

A correspondência entre o Absoluto e a comunicação de Deus se distancia do entendimento de Inefável do neoplatonismo. Para além de uma questão de nomenclatura teológica, na qual Plotino e Proclo se dirigem ao Uno e os cristãos como Pseudo-Dionísio e Eckhart se referem a Deus, a questão passa por uma admissão ontológica ${ }^{7}$. A Inefabilidade do divino não torna vazio o ser, e sim dá ao ser um fundamento abscôndito para além do ser, que torna o ser possível em uma via de acesso que vai para além dele (LOSSKY, 1998, p. 18).

\section{Entre Pseudo-Dionísio e Eckhart}

Como lembra Lossky (1998), há também diferenças entre os semelhantes. Em sua interpretação, a diferença estaria no modo de responder ao Inefável. Enquanto, para PseudoDionísio, a natureza permanece "superessencial", com ênfase permanente no Super, no Über, em Eckhart a transcendência parte do ser, desde o singular da criatura, numa participação em

\footnotetext{
Lossky chama essa diferença de "revelação ontológica do Exôdo", na linha de interpretação de Gilson (2001) que o nomeia similarmente como "metafísica do Exôdo", em que o ser é chamado dialeticamente de volta ao princípio da negação pelo Exôdo 3:14 em que o próprio Deus teria dito: "Sou o que sou". Cf. LOSSKY, 1998, p. 20. CARVALHO, 1996, p. 97.
} 
que o uno não está para além do múltiplo, está contido no múltiplo sem ser ele mesmo um múltiplo. Embora, para Lossky (1998, p. 22), acredite-se que o próprio Pseudo-Dionísio Areopagita não ultrapasse o Inefável divino e mantenha Deus na Inefabilidade, o que em confronto com Carvalho e Gilson não nos parece mais fiel, justo pela aceitação do nome divino por hipérbole e pela teologia superlativa encontramos uma diferença na relação da transcendência com o ser. Para Eckhart, mantém-se um fio tenso, como uma ponte sobre o abismo divino, do ser em dialética com seu fundamento inefável, de tal modo que o ser ainda ocupa um lugar de destaque em sua metafísica.

Em Nomes Divinos, Pseudo-Dionísio também inclui o ser, e o Ser é o nome que integralmente se dá àquele que é. Assim, para que algo seja é necessário "ser" e, desse modo, participe do Ser em si que lhe confere essência e existência. A natureza divina transcende todos os seres enquanto causa e princípio. Desse modo, Deus pode ser nomeado como Inteligência, Sabedoria e Razão, contudo há uma privação da Inteligência, Sabedoria e Razão como a conhecemos. A recusa de tais nomes, embora Pseudo-Dionísio aceite-os com ressalvas, não se trata de uma privação dessas qualidades e sim de uma superioridade em relação a elas. Nas palavras de Cunha, "Ser e Inteligência coincidem e convergem na ideia de Causa primeira que gera a partir de si e do conhecimento que lhe é, substancialmente", pois "os seres criados possuem e permitem o conhecimento analógico de Deus" (AREOPAGITA, 1943, 820 A apud CUNHA, 2015, p. 43). A analogia é a permissão do ser, mesmo inferior, para a nomeação e o conhecimento divino (CUNHA, 2015, p. 43).

A analogia se encontra presente na passagem do ser e do além do ser em Eckhart, e há uma confluência tamanha que poderíamos pensar que um trecho de Os Nomes Divinos poderia ter saído de sua pena, a saber: [Deus por] "não ser nada do que é, não pode ser conhecido pelo que é, e, por não ser nada em nada, é conhecido por tudo em tudo, ao mesmo tempo em que não pode ser conhecido através de nada" (AREOPAGITA, 1943, 820 A apud CUNHA, 2015, p. 48). Uma diferenciação na questão ontológica é que se, para ambos, Deus não é ser, para Eckhart, o ser é Deus (esse est Deus).

O ser é Deus. Esta proposição é evidente. Primeiramente porque, se o ser for diverso do próprio Deus, Deus não é nem é Deus. De que modo, afinal, poderia ser e ser algo, se o ser fosse outro, alheio e distinto dele? Ou, se for Deus, é Deus por causa de outro, sendo o ser outro dele mesmo. Portanto Deus e o ser são o mesmo, ou Deus tem seu ser a partir de um outro. E assim ele não seria o mesmo Deus, como se pressupôs, mas um outro diferente dele seria antes dele, e seria a causa de seu ser. Além disso: tudo o que é, recebe do ser e para o ser o que se torna ou é ou o que é. Portanto, se o ser for alheio a Deus, a coisa recebe o ser de outro, mas não de Deus. Além disso: antes do ser não há nada, uma vez que quem outorga o ser cria e é criador. Porque criar é dar o ser a partir do nada. É manifesto, contudo, que todas as coisas têm o ser do mesmo 
ser, assim como todas as coisas brancas são brancas a partir da brancura. Por conseguinte, se o ser for diverso de Deus, o criador é outro que não Deus. Pelo contrário, toda coisa que tem o ser é, com exclusão de qualquer outra coisa, assim como o que tem a brancura é branco. Portanto, se o ser fosse alheio a Deus, as coisas poderiam ser sem Deus. E assim Deus não seria a causa primeira, nem a causa das coisas que são (ECKHART, 1984 apud e trad. RASCHIETTI, 2012, p. 84).

O ser depende da criação divina, e, como Eckhart já apontava desde o sermão alemão 9, para ser a causa de todo ser Deus deve necessariamente estar além de todo ser, pois, do contrário, não poderia um ser existir como a causa dos seres. Ele é no ser e para além do ser, e por existir o ser, deve-se a existência da causa primeira de Deus. Não há branco para fora da brancura, sendo assim, há o ser na natureza divina que é a correspondência de todo ser, contudo, é por essa mesma natureza estar além que é possível ser ela mesma a criação de toda e qualquer existência.

Deus compartilha a si mesmo em todas as criaturas, participa de suas essências com a própria integralidade, indivisibilidade. Não igual ao fogo, que doa o seu calor e continua enquanto fogo e chama, ou à flor, que doa o seu cheiro e permanece no jardim. Deus, nas palavras de Eckhart, dá o seu, porque o que ele é, é a partir de si mesmo e, em todas as doações que dá, ele primeiramente e sempre dá a si mesmo. Ele se dá como deidade, como ele é em todas as suas doações. Não é isso ou aquilo que Deus dá, não o calor ou o brilho, Deus dá simples e radicalmente o "seu". Nesta noção de compartilhamento, Schuback (2000, p.56) indica haver uma das experiências mais profundas da religiosidade medieval, que é "a apreensão de que o próprio das coisas, a sua unidade, não é uma 'construção' de deus, mas uma participação ou doação" de sua inteireza. As criaturas são como um nada sem Deus, e aqui um nada enquanto pura negação.

A natureza divina, ao contrário, não é pura negação, o seu Nada é pura potencialidade de todo ser. Eckhart, no sermão alemão 21, expressa o sentido de negação ante o ser da criatura: "Todas as criaturas carregam em si uma negação; uma nega ser a outra. Um anjo nega que seja um outro" (ECKHART, 2006, p. 149). Na continuação, compara o sentido de negação ante a natureza divina: "Deus, porém, tem um negar do negar; ele é Um e nega tudo o mais" (ECKHART, 2006, p. 149.). Para Giachini, em nota de rodapé do mesmo trecho, esta é a máxima que condensa a teologia negativa de Mestre Eckhart ${ }^{8}$.

\footnotetext{
${ }^{8}$ GIACHINI, 2006, p. 149: "Nesta afirmação está resumida a explicação do que significa, quando em Eckhart falamos de teologia negativa"
} 
Na distinção dialógica de sua ontologia, Eckhart parte das negações de Pseudo-Dionísio para, em seu pensamento, que relaciona mística e escolástica, chegar à última negação, isto é, à própria negação. Deus é um negar do negar, e, por isso mesmo, uma afirmação absoluta.

\section{REFERÊNCIAS BIBLIOGRÁFICAS}

AREOPAGITA, P.-D. Oeuvres complètes du pseudo-Denys l'Aréopagite. Trad. M. de Gandillac. Paris: Aubier, 1943.

. Dionísio Pseudo-Areopagita: mística e neoplatonismo. Trad. CARVALHO, M.S.

Porto: Ed. Fundação Eng. António de Almeida. Porto, 1996.

CARVAlHO, M. S. de. Pseudo-Dionísio Areopagita - Teologia Mística. Porto: Ed. Fundação Eng. António de Almeida. Porto, 1996.

CUNHA, C. B. Dionísio Pseudo-Areopagita: mística e neoplatonismo. São Paulo: Paulus, 2009.

Porfírio, Dionísio e Mestre Eckhart: considerações sobre a adequação entre ser e inteligência. Princípios - Revista de Filosofia. Natal, v. 22, 2015, p. 31-51.

ECKHART, Mestre. Sermões Alemães vol. 1. Trad. Enio Paulo Giachini. Ed. Universitária São Francisco, Ed. Vozes, 2006.

. Sermões Alemães vol. 2. Trad. Enio Paulo Giachini. Paulo. Ed. Universitária São Francisco, Ed. Vozes, 2009.

Expositio Libri Genesis. Edição bilingue latim-francês: Le Commentaire de la Genèse précédé des Prologues (Org.). A. De Libera, E. Wéber, E. Zum Brunn. Paris: Les Éditions du Cerf, 1984.

GANDILLAC, M. de. Gêneses da Modernidade. Rio de Janeiro: Ed. 34. 1995.

GIACHINI, E. P. Notas e Glossário In: ECKHART, Sermões Alemães Vol.1. Ed. Universitária São Francisco, Ed. Vozes, 2006.

GILSON, E. A filosofia na Idade Média. Tradução Eduardo Brandão. São Paulo: Martins Fontes, 2001.

GUERIZOLI, R. A condenação de Mestre Eckhart: apresentação e tradução da bula papal In Agro Dominico. Síntese - Rev. de Filosofia. Belo Horizonte, v. 27, n. 89, 2000), pp. 387-403.

JARCZYK, G.; LABARRIÈRE, P.-J. Maître Eckhart ou l'empreinte du desert. Paris: Albin Michel, 1995.

LOSSKY, V. Théologie negative et connaissance de Dieu chez Maître Eckhart. Paris: J. Vrin, 1998.

MOTA, L. R. e GONÇALVES, W. C. A niilidade e o anonimato de Deus: o apofaticismo do místico Pseudo-Dionísio, o Areopagita. Interações - Cultura e Comunidade, Belo horizonte, v.9 n.16, 2014, p. 431-452.

RASCHIETTI, M. O uno e o ser no pensamento de Meister Eckhart. Trans/Form/Ação, Marília, vol. 35, 2012, pp. 79-98. 
SCHUBACK, M. S. de C. Para Ler os Medievais - Ensaio de Hermenêutica Imaginativa. Ed. Vozes, 2000.

SCHÜRMANN, R. Wandering Joy: Meister Eckhart's mystical philosophy. Lindisfarne Books, 2001.

VAZ, H. C. de L. Experiência mística e filosofia na tradição ocidental. São Paulo: Edições Loyola, 2000. 